\title{
Effects of ammoniated pearl millet silage on intake, feeding behavior, and blood metabolites in feedlot lambs
}

\author{
Thomaz C. G. de C. Rodrigues ${ }^{1}$ • Poliane M. Freitas ${ }^{1} \cdot$ Edson M. Santos ${ }^{2} \cdot$ Gherman G. L. de Araújo $^{3}$. \\ Aureliano J. V. Pires ${ }^{4} \cdot$ Maria C. C. Ayres ${ }^{1} \cdot$ Lorendane M. de Carvalho $^{5} \cdot$ Jocely G. Souza $^{1}$ • \\ Gleidson G. P. de Carvalho ${ }^{1}$
}

Received: 2 October 2018 / Accepted: 1 May 2019 / Published online: 6 June 2019

(C) Springer Nature B.V. 2019

\begin{abstract}
The aim of this study was to evaluate the effects of urea as an additive in the ensiling of pearl millet on the intake, feeding behavior, and metabolic parameters of feedlot-finished lambs. Thirty-two uncastrated, mixed-breed male lambs were used in the experiment. Diets were composed of pearl millet silage enriched with $0,2,4$, or $6 \%$ urea plus a concentrate containing ground corn, soybean meal, and a mineral mixture. The treatments did not affect feed intake $(P>0.05)$ but influenced $(P<0.05)$ eating time (in $\mathrm{min} /$ day, in $\mathrm{min} / \mathrm{kg}$ of dry matter (DM), and in $\mathrm{min} / \mathrm{kg}$ of neutral detergent fiber (NDF)) and chewing time in $\mathrm{min} / \mathrm{kg}$ of DM. Eating efficiency (in $\mathrm{g} \mathrm{DM} / \mathrm{h}$ and in $\mathrm{g} \mathrm{NDF}$ ap/h) responded linearly $(P<0.05)$ to the increasing urea levels in the silages. By contrast, there was no effect $(P>0.05)$ of diets on the blood protein profile (total proteins and albumin), although the serum urea levels responded quadratically $(P<0.05)$. Increasing urea levels in the silage did not change the blood energy profile (cholesterol and triglycerides) or blood enzyme activity (alanine aminotransferase (ALT), aspartate aminotransferase (AST), and gammaglutamyl transferase (GGT); $P>0.05$ ). In conclusion, the treatment of pearl millet silage with urea does not influence the DM intake or metabolic parameters of lambs, but leads to increased eating time and decreased eating efficiency.
\end{abstract}

Keywords Additive $\cdot$ Idleness $\cdot$ Feed efficiency $\cdot$ Urea levels $\cdot$ Rumination

\section{Introduction}

Sheep production is important in arid and semi-arid regions, where water availability is limited and producers are faced with the challenge of maintaining the supply of feedstuffs with good nutritional content all year round.

Pearl millet (Pennisetum glaucum (L.)) crop has gained attention in forage production due to its adaptability to low soil fertility, excellent biomass production capacity, rapid growth (Ramos et al. 2016), tolerance to acid sandy soils, and ability to grow on saline soils (FAO 2009). Additionally,

Gleidson G. P. de Carvalho

gleidsongiordano@yahoo.com.br

Federal University of Bahia, Salvador, Bahia 40170-100, Brazil

Federal University of Paraíba, Aria, Paraíba, Brazil

Embrapa Semi-Arid, Petrolina, Pernambuco, Brazil

4 Southwest State University of Bahia, Itapetinga, Bahia, Brazil

5 Federal University of Viçosa, Viçosa, Minas Gerais, Brazil it grows during the dry season or in regions prone to dry spells and droughts (Santos et al. 2016), which are conditions under which sorghum (Sorghum bicolor L. moench) or corn (Zea mays L.) would not develop satisfactorily (Carvalho et al. 2018).

In semi-arid areas, rainfall fluctuates seasonally, which makes it difficult to maintain crop production and quality along the year. Preserving forage in the form of silage is thus one of the options to provide high-quality feed to animals despite seasonal climatic changes.

The nutritional properties of pearl millet are compatible with those of forage plants traditionally used for silage production such as corn and sorghum (Amer et al. 2012). Additionally, the silage quality of pearl millet can be further increased through the use of chemical additives during ensiling. One of such additives is urea, which is already used in other types of forage (Eustáquio Filho et al. 2016; Olafadehan and Adebayo 2016) due to its ease of handling and potential to improve fermentation and nutritional properties. However, despite its nutritional value, when ensiled, pearl millet may display undesirable characteristics such as decreased dry matter 
content (Ward et al. 2001), making it less attractive when compared with silages made from traditional forages.

Some researchers (Adogla-Bessa et al. 1999; Lopes and Evangelista 2010) observed that, in addition to controlling anaerobic fermentation and adding nutritional value, urea helps in the control of microorganisms when the material treated with it is exposed to oxygen.

Dietary changes and additive inclusion can modify the digestive environment in ruminants; e.g., causing alterations in microbial synthesis, intake, and performance of these animals (Mertens 1994). These metabolic effects of digestion have a direct impact on feeding behavior parameters. This phenomenon was reported by Barros et al. (2011), who observed changes in the feeding behavior of sheep fed diets containing sugarcane or sugarcane bagasse ammoniated with urea.

Furthermore, these effects are also verified in blood metabolites (Gunun et al. 2016), since urea is metabolized in the liver proportionally to the availability of ruminal ammonia (Huntington and Archibeque 2000). In this way, this additive has the potential to directly affect the protein profile. Liver enzymes and energy may also be affected if changes in intake influence the mobilization of body reserves or body weight gain, as was noted by Oliveira Júnior et al. (2004).

The present study was thus undertaken to evaluate the effects of urea as an additive during the ensiling of pearl millet on the feed intake, feeding behavior, and blood metabolites of feedlot-finished lambs.

\section{Materials and methods}

\section{Experimental area and experimental period}

The study was carried out on the Experimental CaatingaBiome Field and at the Metabolism Unit of the Brazilian Agricultural Research Corporation (Embrapa Semi-Arid), located in Petrolina, PE, Brazil.

\section{Animals, experimental design, and diets}

Thirty-two uncastrated, mixed-breed male lambs with an average initial body weight of $17.39 \pm 2.16 \mathrm{~kg}$, at approximately 4 months of age, were assigned to four treatments in a randomized block design with eight replications. The blocks were established based on the initial body weights of the lambs. A diet based on pearl millet silage ammoniated with increasing levels of urea was incorporated gradually during the adaptation period.

Lambs were housed individually in covered metal stalls measuring approximately $2.0 \mathrm{~m}^{2}$, with concrete floors. The stalls were equipped with feeders and water troughs that were available during the entire experimental period (56 days).
Before the onset of the experiment, the animals were allowed 10 days to adapt to the facilities, diets, and management.

The experiment consisted of two 28-day periods intended for the collection of samples and data. The diet consisted of ground corn, soybean meal, a specific mineral supplement for sheep, and pearl millet silage ammoniated with urea at the levels of $0,2,4$, or $6 \%$ (dry matter basis). The feed had a roughage-to-concentrate ratio of 74:26 and was supplied twice daily. Calculations were made so that orts would be $10 \%$ of the amount consumed on the previous day. Water was available ad libitum.

Experimental diets were formulated as recommended by the NRC (2007). The diets were isonitrogenous and were formulated so as to meet the nutritional requirements of lambs and provide a daily weight gain of $200 \mathrm{~g}$. The centesimal and chemical composition of ingredients and experimental diets are shown in Tables 1 and 2, respectively.

The pearl millet (Pennisetum glaucum L.) cultivar used to produce the silage was ADR 500, developed by ATTO Adriana Sementes $\AA$ and Bonamigo. The plants were collected mechanically and chopped in a forage chopper coupled to the tractor to particles of approximately $2 \mathrm{~cm}$. Urea was then added to the chopped material on the floor of the shed, observing the following proportions: for every $130 \mathrm{~kg}$ of fresh forage, $0.78,1.56$, or $2.34 \mathrm{~kg}$ urea were added, representing the proportions of $0,2,4$, and $6 \%$ (dry matter basis). Half plastic drums of 200-L capacity were used as experimental silos. After weighing and homogenizing the pearl millet with

Table 1 Chemical composition of ingredients used in the experimental diets, on a dry-matter basis

\begin{tabular}{lccc}
\hline Item (\% DM) & \multicolumn{2}{c}{ Ingredient } & \\
\cline { 2 - 4 } & Pearl millet & Ground corn & Soybean meal \\
\hline Dry matter $^{\mathrm{a}}$ & 24.31 & 90.47 & 90.65 \\
Organic matter & 90.96 & 98.39 & 94.58 \\
Mineral matter & 9.04 & 1.61 & 5.42 \\
Crude protein & 10.86 & 8.76 & 54.17 \\
Ether extract & 2.1 & 3.5 & 0.89 \\
NDIP ${ }^{\mathrm{b}}$ (\% CP) & 47.89 & 35.28 & 32.63 \\
ADIP ${ }^{\mathrm{c}}$ (\%) & 14.61 & 11.87 & 1.39 \\
Neutral detergent fiber ap ${ }^{\mathrm{d}}$ & 63.62 & 16.84 & 19 \\
Acid detergent fiber & 34.77 & 5.16 & 9.47 \\
Lignin & 4.16 & 3.86 & 1.31 \\
Cellulose & 30.61 & 1.3 & 8.16 \\
Hemicellulose & 32.29 & 10.93 & 4.47 \\
Non-fibrous carbohydrate & 14.38 & 69.29 & 20.52 \\
\hline${ }^{\mathrm{a}}$ Fresh matter basis & & & \\
${ }^{\mathrm{b}}$ Neutral detergent insoluble protein & & \\
${ }^{\mathrm{c}}$ Acid detergent insoluble protein & & \\
${ }^{\mathrm{d}}$ Corrected for ash and protein & & \\
& & & \\
\hline
\end{tabular}


the urea levels, the material was placed in the silos, compacted by trampling ( $600 \mathrm{~kg}$ of green grass per cubic meter) and sealed with plastic lids and clamps. The material was then stored for approximately 90 days in a covered shed until it was fed to the animals.

\section{Intake and chemical analysis}

During the entire data collection period, samples of feed and orts were collected weekly, in the morning, when the feed to be provided to each animal was weighed. Samples were packed and stored in a freezer at $-20{ }^{\circ} \mathrm{C}$.
Dry matter (method 934.01), mineral matter (MM; method 930.05), crude protein (CP; method 981.10), and ether extract (EE; method 920.39) contents were analyzed in accordance with methods described in AOAC (1990). The concentration of neutral detergent fiber (NDF) was analyzed by the technique described by Mertens (2002), with protein corrections as proposed by Licitra et al. (1996). Acid detergent fiber content (ADF) was determined by following the method of Van Soest et al. (1991), and the lignin content was determined with $72 \%$ sulfuric acid (method 973.18; AOAC 2002).

Non-fibrous carbohydrates (NFC) were estimated using the formula proposed by Hall (2000), as follows:

$\mathrm{NFC}(\mathrm{g} / \mathrm{kg})=1000-[(\mathrm{CP}-\mathrm{CP}$ derived from urea + urea $)+\mathrm{NDFap}+\mathrm{EE}+\mathrm{MM}]$.

Table 2 Centesimal composition of ingredients and chemical composition of experimental diets

\begin{tabular}{|c|c|c|c|c|}
\hline \multirow[t]{2}{*}{ Ingredient (\% DM) } & \multicolumn{4}{|c|}{ Urea in the silage (\%) } \\
\hline & 0 & 2 & 4 & 6 \\
\hline Ground corn & 19.08 & 18.74 & 21.28 & 18.28 \\
\hline Soybean meal & 3.84 & 3.56 & 1.82 & 4.05 \\
\hline Mineral supplement ${ }^{\mathrm{a}}$ & 1.73 & 1.70 & 1.90 & 1.67 \\
\hline Urea & 0.35 & 0.00 & 0.00 & 0.00 \\
\hline Pearl millet silage & 75.00 & 76.00 & 75.00 & 76.00 \\
\hline Total & 100.00 & 100.00 & 100.00 & 100.00 \\
\hline \multicolumn{5}{|c|}{ Chemical composition of diets (\% DM) } \\
\hline Dry matter ${ }^{\mathrm{b}}$ & 38.25 & 37.55 & 40.14 & 37.10 \\
\hline Organic matter & 91.43 & 90.88 & 90.33 & 90.66 \\
\hline Mineral matter & 8.21 & 9.11 & 9.65 & 9.35 \\
\hline Crude protein & 15.22 & 15.81 & 15.01 & 15.55 \\
\hline Ether extract & 2.51 & 2.60 & 2.57 & 2.84 \\
\hline $\operatorname{NDIP}^{\mathrm{c}}(\% \mathrm{CP})$ & 17.63 & 20.10 & 25.61 & 24.56 \\
\hline $\operatorname{ADIP}^{\mathrm{d}}(\% \mathrm{CP})$ & 7.84 & 8.78 & 10.98 & 12.79 \\
\hline Neutral detergent fiber ${ }^{\mathrm{e}}$ & 44.51 & 48.32 & 49.86 & 52.85 \\
\hline Acid detergent fiber & 28.00 & 28.78 & 31.64 & 34.69 \\
\hline Lignin & 3.23 & 4.15 & 4.97 & 6.25 \\
\hline Cellulose & 24.77 & 24.63 & 26.67 & 28.44 \\
\hline Hemicellulose & 16.54 & 18.83 & 18.43 & 18.11 \\
\hline Non-fibrous carbohydrates ${ }^{\mathrm{e}}$ & 29.30 & 24.26 & 24.02 & 18.53 \\
\hline Total digestible nutrients & 56.92 & 58.85 & 59.62 & 58.70 \\
\hline
\end{tabular}

${ }^{\text {a }}$ Provides per $1000 \mathrm{mg}$ (minimum): calcium, $141.48 \mathrm{~g}$; phosphorus, $43 \mathrm{~g}$; sodium, $214.50 \mathrm{~g}$; sulfur, $16 \mathrm{~g}$; copper, $700 \mathrm{mg}$; cobalt, $50 \mathrm{mg}$; iron, $2700 \mathrm{mg}$; iodine, $50 \mathrm{mg}$; manganese, $1500 \mathrm{mg}$; selenium, $25 \mathrm{mg}$; zinc, $1800 \mathrm{mg}$; chlorine, $330 \mathrm{~g}$; fluorine, $431 \mathrm{mg}$

${ }^{\mathrm{b}}$ Expressed as \% fresh matter

${ }^{\mathrm{c}} N D I P$, neutral detergent insoluble protein,

${ }^{\mathrm{d}} A D I P$, acid detergent insoluble protein

${ }^{\mathrm{e}}$ Corrected for ash and protein
Feces and orts were collected during the feeding behavior evaluation day by the total collection method, using appropriate canvas bags that were attached to the animals with nylon strips. Samples were mixed and a composite sample was made and dried at $55^{\circ} \mathrm{C}$ for $72 \mathrm{~h}$ and then stored for further analysis. Samples of feed, orts, and feces were then thawed, weighed, and dried in a forced air oven at $55^{\circ} \mathrm{C}$ for $72 \mathrm{~h}$. Subsequently, they were ground to $1-\mathrm{mm}$ particles (Willye TE-680, TECNAL, Brazil), homogenized, and stored for further analysis.

\section{Feeding behavior evaluation and calculations}

At the end of each experimental period, the animals were observed for $24 \mathrm{~h}$, at 5-min intervals, to evaluate their feeding behavior (Carvalho et al. 2007), which comprised eating, ruminating, and idle activities. The number of chews per cud and the time taken to ruminate each cud in these periods were recorded (Polli et al. 1996). In the nighttime observation, the environment was illuminated artificially.

After eating, ruminating, and idle activities were recorded, the behavioral variables were calculated. Eating efficiency was calculated as feed intake (in grams) divided by the time taken to consume the feed (in minutes). The expressions were adapted from Burgüer et al. (2000).

\section{Evaluation of blood metabolites}

Blood was collected on the second to last experimental day, 4 hours after the morning feed, by jugular venipuncture. After local antisepsis, $10-\mathrm{mL}$ blood samples were collected in tubes without anticoagulant (SST II Advance, BD Vacutainer, São Paulo, Brazil). Centrifugation was then performed at $1465 \mathrm{~g}$ for $15 \mathrm{~min}$ to obtain the blood serum, which was transferred to Eppendorf microcentrifuge tubes and stored at $-20{ }^{\circ} \mathrm{C}$ for later analysis. 
The serum total protein (biuret method) and albumin (bromocresol green method) concentrations $(\mathrm{g} / \mathrm{dL})$ were obtained using commercial kits (Doles, Goiânia, Brazil). The serum concentrations of urea $(\mathrm{mg} / \mathrm{dL})$ and total cholesterol $(\mathrm{mg} / \mathrm{dL})$ and triglycerides $(\mathrm{mg} / \mathrm{dL})$, which were used to evaluate the energy profile, were analyzed using commercial kits (Doles, Goiânia, Brazil) and the enzymatic colorimetric technique, with the reading performed in a semi-automatic biochemical analyzer (SBA-200, Barueri, Brazil).

The alanine aminotransferase (ALT; IU/L), aspartate aminotransferase (AST; IU/L), and gamma-glutamyl transferase (GGT; IU/L) enzyme activities were used to evaluate the hepatic metabolism. These were measured by colorimetric analysis using commercial kits (Doles, Goiânia, Brazil). The catalytic activity was measured in a spectrophotometer. All samples were run at once for all measured variables.

\section{Statistical analysis}

A randomized block design with four treatments (levels of urea addition to pearl millet silage) and eight replicates (lambs) per treatment was adopted in which the blocks corresponded to the body weight intervals, according to the mathematical model below:

$\gamma i j=\mu+\tau i+\beta j+\varepsilon i j$

where $\gamma i j=$ value observed in the plot that received treatment $i$ in block $j ; \mu=$ overall mean; $\pi i=$ effect of treatment $i ; \beta j=$ effect of block $j$; and $\varepsilon i j=$ random error associated with treatment $i$ and block $j$.

Results were subjected to analysis of variance (ANOVA) and regression at the 5\% probability level for type I error, and the effect of treatments was evaluated by orthogonal polynomials, by decomposing the sum of squares into linear and quadratic effects, using the Statistical Analysis System (SAS Institute Inc., Cary, NC) (SAS software 9.0). Regression equations were described in the manuscript, where $x$ is the independent variable related to the amount $(\mathrm{g} / \mathrm{kg})$ of urea added to pearl millet silage and $Y$ is the evaluated dependent variable.

\section{Results}

The intakes of dry matter (DMI) and neutral detergent fiber (NDFI) were not influenced by the urea levels used in the ensiling of pearl millet $(P>0.05)$, averaging $618.33 \mathrm{~g}$ and $195.98 \mathrm{~g}$, respectively (Table 3 ). Contrarily, urea levels elicited a quadratic response $(P=0.034)$ from eating time in minutes per day ( $\mathrm{min} /$ day) and a linear response when this variable was expressed in minutes per kilogram of DM $(\mathrm{min} / \mathrm{kg}$ $\mathrm{DM})(P=0.004)$ and in minutes per kilogram of fiber $(\mathrm{min} / \mathrm{kg}$ NDFap) $(P=0.018)$.
Ruminating time (min/day, $\min / \mathrm{kg}$ DM, and $\mathrm{min} / \mathrm{kg}$ NDFap) and idle time ( $\mathrm{min} /$ day) were not affected $(P>0.05)$ by the diets (Table 3). Similarly, the number of chews per cud (n/cud), number of daily chews (n/day), chewing time in hours per cud ( $\mathrm{s} / \mathrm{cud}$ ), chewing time in hours per day (h/day), and chewing time in minutes per kilogram of fiber ( $\mathrm{min} / \mathrm{kg}$ NDFap) were not affected by the diets $(P>0.05)$, averaging 60.98, 2649, 42.42, 8.83 , and 2960, respectively (Table 3). However, chewing time in minutes per kilogram of DM ( $\mathrm{min} / \mathrm{kg} \mathrm{DM})$ increased linearly $(P=0.019)$ with the urea levels (Table 3$)$.

Eating efficiency expressed in grams of DM $(\mathrm{g} \mathrm{DM} / \mathrm{h})$ and fiber $(\mathrm{g} \mathrm{NDFap} / \mathrm{h})$ per hour decreased linearly $(P=0.005$ and $P=0.026$, respectively). The maximum values for the respective variables were obtained with the silage ammoniated with $2 \%$ urea (DM basis). There was no effect of diets $(P>0.05)$ on ruminating efficiency in grams of DM $(P=0.907)$ and NDFap $(P=0.927)$ per hour, which averaged 125.95 and 40.69 , respectively (Table 4). No statistical difference was found between the evaluated treatments for number of cuds ruminated per day (n/day) $(P>0.05$; Table 4$)$.

The numbers of meals in 1 day ( $\mathrm{n} /$ day) responded quadratically $(P<0.01$; Table 5$)$. The number of idle periods during the day $(\mathrm{n} /$ day) increased linearly $(P=0.04)$, with the maximum value obtained with $6 \%$ urea (DM basis) (Table 5). Therefore, the times the animals spent ruminating ( $\mathrm{n} /$ day and $\min$ ), eating ( $\mathrm{min}$ ), and idle ( $\mathrm{min})$ were not affected by the diets (Table 5). Additionally, the average time these animals took to consume $1 \mathrm{~kg}$ of DM per period decreased linearly, with the minimum time observed at $6 \%$ inclusion of urea in the silage. The time taken to consume NDFap responded quadratically to the diets (Table 5).

In the analysis of blood metabolites (Table 6), there was no diet effect $(P>0.05)$ on the protein profile (serum levels of total protein $(\mathrm{g} / \mathrm{dL})$ and albumin $(\mathrm{g} / \mathrm{dL}))$. However, the diets had a linear effect $(P=0.00027)$ on the serum urea $(\mathrm{mg} / \mathrm{dL})$ concentration, which ranged from 32.96 to $48.52(\mathrm{mg} / \mathrm{dL})$ (Table 6). The diets did not influence the energy profile (cholesterol and triglycerides) $(P<0.05)$ (Table 7). Results ranged from 19.5 to 25.33 $(\mathrm{mg} / \mathrm{dL})$ for cholesterol and from 32.9 to $48.52(\mathrm{mg} / \mathrm{dL})$ for triglycerides, both of which are within the normal range (Table 7). Enzyme activities (ALT, AST, and GGT) were not affected $(P>0.05)$ by the increasing urea levels in the pearl millet silage, averaging $70.64,18.12$, and 55.82 (IU/L) (Table 8).

\section{Discussion}

The introduction of an unconventional feedstuff may change the intake and feeding behavior of animals. According to the present results (Table 3), the treatment of silage with urea did not influence the intakes of DM or NDF up to the urea level of $6 \%$ DM. Similar findings were reported by Silva et al. (2007), who also did not observe differences between the DMI and 
Table 3 Intakes of dry matter (DM) and neutral detergent fiber corrected for ash and protein (NDFap) and eating, rumination, chewing, and idle activities of lambs fed diets based on pearl millet silage ammoniated with urea

\begin{tabular}{|c|c|c|c|c|c|c|c|}
\hline \multirow[t]{2}{*}{ Item } & \multicolumn{4}{|c|}{ Urea in the silage $(\%)$} & \multirow[t]{2}{*}{ SEM } & \multicolumn{2}{|c|}{$P$ value* } \\
\hline & 0 & 2 & 4 & 6 & & $\mathrm{~L}$ & Q \\
\hline \multicolumn{8}{|c|}{ Intake in $24 \mathrm{~h}(\mathrm{~g} /$ day $)$} \\
\hline $\mathrm{DM}$ & 648.3 & 660 & 616.2 & 548.8 & 25.81 & 0.154 & 0.640 \\
\hline NDFap & 191.5 & 220.1 & 196.2 & 176.1 & 10.61 & 0.761 & 0.312 \\
\hline \multicolumn{8}{|l|}{ Eating } \\
\hline $\mathrm{min} /$ day & 211.3 & 206.1 & 219.5 & 286.5 & 8.96 & 0.003 & 0.034 \\
\hline $\mathrm{min} / \mathrm{kg} \mathrm{DM}$ & 341.6 & 327.8 & 375 & 551.6 & 25.81 & 0.004 & 0.057 \\
\hline $\mathrm{min} / \mathrm{kg}$ NDFap & 1160.8 & 1035.8 & 1204 & 1758.5 & 91.00 & 0.018 & 0.071 \\
\hline \multicolumn{8}{|l|}{ Ruminating } \\
\hline $\mathrm{min} /$ day & 309.4 & 327.8 & 312.6 & 275.5 & 15.38 & 0.635 & 0.567 \\
\hline $\mathrm{min} / \mathrm{kg} \mathrm{DM}$ & 483.7 & 494.8 & 513.9 & 496.4 & 18.21 & 0.946 & 0.938 \\
\hline $\mathrm{min} / \mathrm{kg}$ NDFap & 1639.23 & 1607.51 & 1685 & 1698.89 & 94.57 & 0.979 & 0.999 \\
\hline \multicolumn{8}{|l|}{ Chewing } \\
\hline $\mathrm{n} / \mathrm{cud}$ & 63.04 & 59.75 & 56.25 & 64.87 & 1.41 & 0.220 & 0.284 \\
\hline s/cud & 41.33 & 43.75 & 40.05 & 44.55 & 0.75 & 0.535 & 0.695 \\
\hline $\mathrm{n} /$ day & $28,271.32$ & $27,092.1$ & $26,330.06$ & $24,267.43$ & 140.9 & 0.438 & 0.995 \\
\hline $\mathrm{h} /$ day & 8.68 & 8.4 & 8.87 & 9.37 & 0.30 & 0.672 & 0.985 \\
\hline $\min / \mathrm{kg} \mathrm{DM}$ & 825.28 & 822.59 & 888.93 & 1047.99 & 33.4 & 0.019 & 0.230 \\
\hline $\mathrm{min} / \mathrm{kg}$ NDFap & 2800.01 & 2693.3 & 2889.97 & 3457.39 & 158 & 0.177 & 0.434 \\
\hline \multicolumn{8}{|l|}{ Idle } \\
\hline $\mathrm{min} /$ day & 919.4 & 906 & 907.9 & 878 & 17.82 & 0.672 & 0.985 \\
\hline \multicolumn{8}{|c|}{ Regression equation } \\
\hline \multicolumn{8}{|l|}{ Eating } \\
\hline $\mathrm{min} /$ day & \multicolumn{4}{|c|}{$Y=212.865-13.0315 x+4.18390 x^{2}$} & & \multicolumn{2}{|c|}{$\left(R^{2}=0.99\right)$} \\
\hline $\mathrm{min} / \mathrm{kg} \mathrm{DM}$ & \multicolumn{4}{|c|}{$Y=304.139+32.5050 x$} & & \multicolumn{2}{|c|}{$\left(R^{2}=0.71\right)$} \\
\hline $\min / \mathrm{kg}$ NDFap & \multicolumn{4}{|c|}{$Y=1050.31+89.1671 x$} & & \multicolumn{2}{|c|}{$\left(R^{2}=0.64\right)$} \\
\hline \multicolumn{8}{|l|}{ Chewing } \\
\hline $\mathrm{min} / \mathrm{kg} \mathrm{DM}$ & \multicolumn{4}{|c|}{$Y=790.874+36.5514$} & & \multicolumn{2}{|c|}{$\left(R^{2}=0.81\right)$} \\
\hline
\end{tabular}

$S E M$, standard error of the mean; $L$, significance for linear effects; $Q$, significance for quadratic effects

*There was no significant block effect
NDFI despite the use of ammoniation. To better understand the effects of the additive, we obtained a regression equation for DMI that showed a quadratic response, with maximum point at the addition of $1.56 \%$ urea to the ensiled material.

It is well recognized that changes in diet composition, roughage source, and management have impacts on rumen function and eating and ruminating behavior (Van Soest 1994; Beauchemin 2018). The longer time spent eating when higher urea contents were present in the silage is possibly due to the stronger odor caused by ammonia. This odor likely decreased the acceptability of the feed, which may have resulted in more time spent sorting through it. The current results agree with the ammoniacal nitrogen values found by Carvalho et al. (2018) in millet silages ammoniated with urea. Additional results that confirm the findings of the present study are those obtained by Perazzo et al. (2017) with the use of buffel grass hay ammoniated with urea in lamb diets.
Rumination time is influenced by the nature of the diet; it is proportional to the cell wall content of feedstuffs and to the increase in NDF (Van Soest 1994). However, the fact that ammonia leads to changes in the cell wall content of forages and that the NDF contents were not similar were not sufficient to alter the time the animals spent ruminating. The average time the lambs spent ruminating was $306.33 \mathrm{~min} /$ day, which corresponds to approximately $39 \%$ of their daily activities.

Although the time spent idle did not differ across treatments, the lambs spent most of their time idling, which is compatible with the idle times spent by animals fed diets with higher concentrate levels, as reported by Burgüer et al. (2000).

The number of chews and the time spent chewing per cud are influenced by the dietary fiber content, which, in this study, did not have significant differences to the point of altering those activities. The number of cuds per day is dependent upon the ruminating and chewing time per cud, which explains the lack of a significant effect on number of cuds per 
Table 4 Feed and rumination efficiency of lambs fed diets based on pearl millet silage ammoniated with urea

\begin{tabular}{|c|c|c|c|c|c|c|c|}
\hline \multirow[t]{2}{*}{ Item } & \multicolumn{4}{|c|}{ Urea in the silage (\%) } & \multirow[t]{2}{*}{ SEM } & \multicolumn{2}{|c|}{$P$ value* } \\
\hline & 0 & 2 & 4 & 6 & & $\mathrm{~L}$ & Q \\
\hline \multicolumn{8}{|c|}{ Eating efficiency } \\
\hline $\mathrm{g} \mathrm{DM} / \mathrm{h}$ & 190.93 & 197.35 & 169.67 & 117.93 & 9.62 & 0.005 & 0.112 \\
\hline g NDFap/h & 56.08 & 66.05 & 53.61 & 37.14 & 3.39 & 0.026 & 0.051 \\
\hline \multicolumn{8}{|c|}{ Ruminating efficiency } \\
\hline $\mathrm{g} \mathrm{DM} / \mathrm{h}$ & 128.73 & 128.28 & 122.07 & 124.72 & 4.66 & 0.907 & 0.993 \\
\hline g NDFap/h & 37.64 & 43.73 & 39.26 & 42.11 & 2.55 & 0.927 & 0.989 \\
\hline g DM/cud & 1.49 & 1.55 & 1.35 & 1.54 & 0.06 & 0.998 & 0.831 \\
\hline g NDFap/cud & 0.43 & 0.52 & 0.43 & 0.51 & 0.03 & 0.845 & 1.000 \\
\hline Cuds (n/day) & 454.4 & 454.92 & 463.6 & 366.25 & 21.57 & 1.000 & 0.066 \\
\hline \multicolumn{8}{|c|}{ Regression equation } \\
\hline \multicolumn{8}{|c|}{ Eating efficiency } \\
\hline $\mathrm{g} \mathrm{DM} / \mathrm{h}$ & \multicolumn{4}{|c|}{$Y=203.364-11.9248 x$} & & \multicolumn{2}{|c|}{$\left(R^{2}=0.78\right)$} \\
\hline g NDFap/h & \multicolumn{4}{|c|}{$Y=61.9557-3.21620 x$} & & \multicolumn{2}{|c|}{$\left(R^{2}=0.55\right)$} \\
\hline
\end{tabular}

$S E M$, standard error of the mean; $L$, significance for linear effects; $Q$, significance for quadratic effects

*There was no significant block effect

day. Besides, the particle size of the diet ingredients has a greater influence on these parameters, and because the silages were produced under the same conditions, the values for chewing activities were not influenced.
Table 6 Serum levels of urea, total proteins (TP), and albumin of lambs fed diets based on pearl-millet silage ammoniated with urea

\begin{tabular}{|c|c|c|c|c|c|c|c|}
\hline \multirow[t]{2}{*}{ Item } & \multicolumn{4}{|c|}{ Urea in the silage $(\%)$} & \multirow[b]{2}{*}{ SEM } & \multicolumn{2}{|c|}{$P$ value* } \\
\hline & 0 & 2 & 4 & 6 & & $\mathrm{~L}$ & Q \\
\hline Urea (mg/dL) & 35.25 & 37.24 & 32.96 & 48.52 & 1.704 & 0.0003 & 0.001 \\
\hline $\mathrm{TP}(\mathrm{g} / \mathrm{dL})$ & 6.65 & 6.72 & 6.45 & 6.44 & 0.085 & 0.249 & 0.978 \\
\hline Albumin $(\mathrm{g} / \mathrm{dL})$ & 2.8 & 2.7 & 2.8 & 2.64 & 0.065 & 0.742 & 0.983 \\
\hline \multicolumn{8}{|c|}{ Regression equation } \\
\hline Urea (mg/dL) & \multicolumn{7}{|c|}{$Y=33.1299+1.82421 x\left(R^{2}=0.44\right)$} \\
\hline
\end{tabular}

$S E M$, standard error of the mean; $L$, significance for linear effects; $Q$, significance for quadratic effects

*There was no significant block effect

Lambs fed the diet with the highest urea levels spent the most time chewing per kilogram of DM. These were also the animals that took the longest time eating and that had the lowest DM intake.

The decreasing linear effect for eating efficiency expressed in $\mathrm{g} \mathrm{DM} / \mathrm{h}$ and $\mathrm{g}$ NDFap/h was possibly due to the different times spent eating and the amount consumed. As reported by Dado and Allen (1994), the time spent eating per unit of NDF intake increased with added dietary NDF.

Ruminating efficiency in $\mathrm{g} \mathrm{DM} / \mathrm{h}$ and $\mathrm{g}$ NDFap/h is related to DMI and NDFI and to the time spent eating, which did not differ across the diets. Rumination efficiency is an important
Table 5 Number and average time spent per period on the eating, rumination, and idle activities and intakes of dry matter (DM) and neutral detergent fiber corrected for ash and protein (NDFap) per eating period by lambs fed diets based on pearl millet silage ammoniated with urea

\begin{tabular}{|c|c|c|c|c|c|c|c|}
\hline \multirow[t]{2}{*}{ Item } & \multicolumn{4}{|c|}{ Urea in the silage $(\%)$} & \multirow[t]{2}{*}{ SEM } & \multicolumn{2}{|c|}{$P$ value* } \\
\hline & 0 & 2 & 4 & 6 & & $\mathrm{~L}$ & $\mathrm{Q}$ \\
\hline \multicolumn{8}{|c|}{ Number of periods (bouts/day) } \\
\hline Meals & 6.8 & 7.3 & 7.3 & 10.7 & 0.3 & $<0.01$ & $<0.01$ \\
\hline Rumination & 13.5 & 13.5 & 13.9 & 12.6 & 0.3 & 0.63 & 0.31 \\
\hline Idle & 20.5 & 20 & 21 & 22.7 & 0.4 & 0.04 & 0.17 \\
\hline \multicolumn{8}{|c|}{ Time spent per period (min) } \\
\hline Meals & 31.4 & 28.4 & 30.1 & 26.8 & 0.85 & 0.15 & 1.00 \\
\hline Rumination & 22.8 & 24.2 & 22.1 & 21.5 & 0.92 & 0.72 & 0.87 \\
\hline Idle & 45.5 & 45.4 & 43.8 & 39.3 & 1.39 & 0.15 & 0.68 \\
\hline \multicolumn{8}{|c|}{ Average intake per eating period $(\mathrm{kg})$} \\
\hline $\mathrm{DM}$ & 0.098 & 0.092 & 0.085 & 0.052 & 0.05 & $<0.01$ & 0.11 \\
\hline NDFap & 0.029 & 0.030 & 0.027 & 0.016 & 0 & 0.01 & 0.05 \\
\hline \multicolumn{8}{|c|}{ Regression equation } \\
\hline \multicolumn{8}{|c|}{ Number of periods (n/day) } \\
\hline Meals & \multicolumn{4}{|c|}{$Y=6.91813-0.493317 x+0.182331 x^{2}$} & & \multicolumn{2}{|c|}{$\left(R^{2}=0.92\right)$} \\
\hline Idling & \multicolumn{4}{|c|}{$Y=19.9990+0.366184 x$} & & \multicolumn{2}{|c|}{$\left(R^{2}=0.70\right)$} \\
\hline \multicolumn{8}{|c|}{ Average intake per eating period (kg) } \\
\hline DM & \multicolumn{4}{|c|}{$Y=0.102720-0.00707727 x$} & & \multicolumn{2}{|c|}{$\left(R^{2}=0.83\right)$} \\
\hline NDFap & \multicolumn{4}{|c|}{$Y=0.0312628-0.00197648 x$} & & \multicolumn{2}{|c|}{$\left(R^{2}=0.70\right)$} \\
\hline
\end{tabular}

$S E M$, standard error of the mean; $L$, significance for linear effects; $Q$, significance for quadratic effects

*There was no significant block effect 
Table 7 Energy profile of lambs fed diets based on pearl millet silage ammoniated with urea

\begin{tabular}{|c|c|c|c|c|c|c|c|}
\hline \multirow[t]{2}{*}{ Metabolite (mg/dL) } & \multicolumn{4}{|c|}{ Urea in the silage (\%) } & \multirow[t]{2}{*}{ SEM } & \multicolumn{2}{|c|}{$P$ value* } \\
\hline & 0 & 2 & 4 & 6 & & $\mathrm{~L}$ & Q \\
\hline Chole & 24.83 & 19.5 & 25.17 & 25.33 & 1.015 & 0.685 & 0.239 \\
\hline Triglycerides & 65.56 & 69.96 & 73.46 & 66 & 2.475 & 0.991 & 0.321 \\
\hline
\end{tabular}

$S E M$, standard error of the mean; $L$, significance for linear effects; $Q$, significance for quadratic effects

*There was no significant block effect

mechanism to assess the use of low-digestibility feedstuffs because this information allows us to determine whether the dietary NDF is causing decreased intake and consequently lower production performance (Perazzo et al. 2016). The number of cuds ruminated per day (n/day) is related to DMI, which was not significantly affected by the urea levels in the silage.

The average time per activity period (ruminating, eating, and idling) can be influenced by dietary properties like the fiber content (Morais et al. 2006). However, because of the small variations in fiber content of the diets, there was no influence of fiber on these parameters.

The linear decrease in the average intakes per eating period expressed as kilograms of DM and NDFap may be related to the intake and number of meals. As the inclusion level was increased, animals reduced their intake (Table 3 ) and the number of meals (Table 5), which culminated in a low intake per period that ranged from 0.052 to 0.098 for $\mathrm{DM}$ and 0.016 to 0.030 for NDFap (Table 5).

Blood metabolites are an important tool to evaluate the diet effects on the animal health status and metabolism (Chaves et al. 2008; Gobindram et al. 2016; Shakeri 2016; Costa et al. 2018; Odhaib et al. 2018).

There was a linear increase in serum urea levels (Table 6). However, the results were within the normal range described for the ovine species (Kaneko et al. 1997), except for the

Table 8 Aspartate aminotransferase (AST), alanine aminotransferase (ALT), and gamma-glutamyl transferase (GGT) enzyme activities in lambs fed diets based on pearl millet silage ammoniated with urea

\begin{tabular}{|c|c|c|c|c|c|c|c|}
\hline \multirow[t]{2}{*}{ Variable (IU/L) } & \multicolumn{4}{|c|}{ Urea in the silage (\%) } & \multirow[t]{2}{*}{ SEM } & \multicolumn{2}{|c|}{$P$ value* } \\
\hline & 0 & 2 & 4 & 6 & & $\mathrm{~L}$ & Q \\
\hline AST & 73.83 & 69 & 71.12 & 68.62 & 1.656 & 0.631 & 0.964 \\
\hline ALT & 19.62 & 19.12 & 16.87 & 16.87 & 0.729 & 0.119 & 0.993 \\
\hline GGT & 53.25 & 54.75 & 58 & 57.28 & 1.533 & 0.288 & 0.951 \\
\hline
\end{tabular}

$S E M$, standard error of the mean; $L$, significance for linear effects; $Q$, significance for quadratic effects

*There was no significant block effect
$48.52 \mathrm{mg} / \mathrm{dL}$ found in the diet with $6 \%$ urea. On the other hand, Gobindram et al. (2016) and Costa et al. (2018) found serum urea concentrations of up to $50.0 \mathrm{mg} / \mathrm{dL}$ in sheep after changing the levels of ingredients in the diets. It is believed that the $\mathrm{NH}_{3}$ concentration in the rumen increased according to the use of silages with urea, which explains the elevation of serum levels, since the $\mathrm{NH}_{3}$ absorbed by the rumen wall enters the bloodstream and is transformed into urea in the urea cycle. The present results corroborate the findings of Odhaib et al. (2018), who changed the ingredient in lamb diets, and observed decreased ruminal ammonia concentrations and, consequently, decreased serum urea concentrations, which the authors attributed to an improvement in protein metabolism efficiency. According to Andrade-Montemayor et al. (2009), high blood urea concentrations are associated with situations in which there is a higher intake of protein and lower energy intake or even unsynchronized degradation of energy and protein.

Serum albumin values were not affected by the diets, remaining within the acceptable range and similar to those reported by Meira Jr et al. (2009) and Araujo et al. (2014). In addition, the lack of differences between treatments for the albumin concentrations may be related to the similar use of the dietary $\mathrm{CP}$ by the animals (Rezaei et al. 2013).

The serum concentrations of plasma cholesterol and triglycerides were within the normal range as compared with those obtained in experiments with sheep (Santos et al. 2011; Borburema et al. 2012; Araujo et al. 2014). In a study led by Costa et al. (2018), the inclusion of an agro-industrial waste in the diet of lambs reduced their cholesterol by $30 \%$ and increased their serum concentration of thyroid hormones. Changes in the dietary lipid content were low, which possibly contributed to this result. Therefore, these parameters are indispensable in a battery of biochemical tests, because they allow not only for detecting the presence of an energy deficit but also evaluating the use of body reserves (Araujo et al. 2014).

The AST, ALT, and GGT enzymes remained within the normal levels for the ovine species (Table 8), indicating that the liver function of the lambs was not compromised (Pugh and Dum 2005; Przemysław et al. 2015). The lack of effects of the silage ammoniated with urea on the enzymatic profile implies that the diets did not lead to degeneration of liver cells, considering that these enzymes are released into the blood stream in the case of a cell lesion or when the hepatocyte membrane integrity is compromised (Kaneko et al. 2008).

When used as the roughage component in diets for feedlot lambs, pearl-millet silages produced with up to $6 \%$ urea does not influence the DM intake or blood metabolites of lambs, but leads to increased eating time and decreases eating efficiency. 
Acknowledgments We thank the machine learning engineer at Duolingo, Bill McDowell M.Sc., for the English corrections.

Funding information This study was financed in part by the Coordination for the Improvement of Higher Education PersonnelBrazil (CAPES) (Grant no. 001).

\section{Compliance with ethical standards}

Statement of animal right The authors declare that all experimental procedures were conducted in accordance with the current law of the country and were approved by the Ethics Committee of Animal Experimentation (no.05-2016).

Conflict of interest The authors declare that they have no conflict of interest.

\section{References}

Adogla-Bessa, T., Owen, E., Adesogan, A. T. 1999. Ensiling of whole crop wheat with cellulase-hemicellulase based enzymes: 3 . Comparing effects of urea or enzyme treatment on forage composition and stability. Animal feed science and technology, 82, 51-61.

Amer, S., Hassanat, F., Berthiaume, R., Seguin, P., Mustafa, A.F. 2012. Effects of water soluble carbohydrate content on ensiling characteristics, chemical composition and in vitro gas production of forage millet and forage sorghum silages. Animal Feed Science and Technology, 177, 23-29.

Andrade-Montemayor, H.A., Gasca, T.G., Kawas, J. 2009. Ruminal fermentation modification of protein and carbohydrate by means of roasted and estimation of microbial protein synthesis. Revista Brasileira de Zootecnia, 38, 277-291.

AOAC. 1990. Official Methods of Analysis, 12th ed. Association of Official Analytical Chemists, Arlington, VA.

AOAC. 2002. Official Methods of Analysis. Gaithersburg, VA: Association of Official Analytical Chemists.

Araujo, M.L.G.M.L., Carvalho, G.G.P., Ayres, M. C.C., Bezerra, L.S., Rebouças, R.A., Vieira Filho, C.H C., Oliveira, R.L., Silva, T.M., Leite, J.K.C., Teixeira, C.S.C. 2014. Assessment of the metabolic, protein, energy, and liver profiles of lambs finished in a feedlot and receiving diets containing groundnut cake. Tropical Animal Health and Production, 46, 433-437.

Barros, R.C., Rocha Júnior, V.R., Saraiva, E.P., Mendes, G.A., Meneses, G.C.C., Oliveira, C.R., Rocha, W.J.B., Aguiar, A.C.R., Santos, C.C.R. 2011. Ingestive behavior of feedlot Nellore cattle with different levels of substitution of sorghum silage for sugarcane or sugarcane bagasse ammoniated with urea. Revista Brasileira de Ciência Veterinária, 18, 6-13.

Beauchemin, K. A. 2018. Invited review: Current perspectives on eating and rumination activity in dairy cows. Journal of dairy science, 101, 4762-4784.

Borburema, J.B., Cezar, M.F., Marques, D.D., Cunha, M.G.G., Pereira Filho, J.M., Sousa, W.H., Furtado, D.A., Costa, R.G. 2012. Effect of diet on the metabolic profile of Santa Inês sheep feedlot. Arquivo Brasileiro de Medicina Veterinária e Zootecnia, 64, 983-990.

Burgüer, P.J., Pereira, J.C., Queiroz, A.C., Silva, J.F.C., Valadares Filho, S.C., Cecon, P.R., Casali, A.D.P. 2000. Ingestive behavior in Holstein calves fed diets with different concentrate levels. Revista Brasileira de Zootecnia, 29, 236-242.

Carvalho, G.G.P., Pires, A.J.V., Silva, H.G.D.O., Veloso, C.M., Silva, R.R. 2007. Methodological aspects of chewing activity of dairy goats fed cocoa meal or palm cake. Revista Brasileira de Zootecnia, 36, 103-110.

Carvalho, G.G.P., Freitas, P.M.D., Santos, E.M., Araújo, G.G.L., Oliveira, J.S., Pires, A.J.V., Maranhão, C.M.A., Rodrigues, T.C.G.C., Freitas-Junior, J.E., Rufino, L.M.A., Rodrigues, C.S., Leite, L.C., Araujo, M.L.G.M.L. 2018. Effect of pearl millet silage ammoniated with urea on lamb production and metabolic performance. Grass and Forage Science, 73, 685-693.

Chaves, A. V., Stanford, K., Dugan, M. E. R., Gibson, L. L., McAllister, T. A., Van Herk, F., \& Benchaar, C. (2008). Effects of cinnamaldehyde, garlic and juniper berry essential oils on rumen fermentation, blood metabolites, growth performance, and carcass characteristics of growing lambs. Livestock Science, 117(2-3), 215224.

Costa, R. G., Ribeiro, N. L., Nobre, P. T., Carvalho, F. F., Medeiros, A. N., Cruz, G. R., Freire, L. F. 2018. Biochemical and hormonal parameters of lambs using guava (Psidium guajava L.) agro-industrial waste in the diet. Tropical animal health and production, 50, 217 221.

Dado, R. G. and Allen, M. S. 1994. Variation in and relationships among feeding, chewing, and drinking variables for lating dairy cows. Journal of Dairy Science 77:132-144.

Eustáquio Filho, A., Carvalho, G.G.P., Pires, A.J.V., Silva, R.R., Santos P.E.F., Murta, R.M., Pereira, F.M., Carvalho, B.M.A., Maranhão, C.M.A., Rufino, L.M.A., Santos, S.A., Pina, D.S. 2016. Intake and ingestive behavior in lambs fed low-digestibility forages. Tropical Animal Health and Production, 48, 1315-1321.

FAO, 2009. Grassland Index. A searchable catalogue of grass and forage legumes. FAO.

Gobindram, M. N. E., Bognanno, M., Luciano, G., Lanza, M., \& Biondi, L. 2016. Carob pulp inclusion in lamb diets: effect on intake, performance, feeding behaviour and blood metabolites. Animal Production Science, 56(5), 850-858.

Gunun, N., Wanapat, M., Gunun, P., Cherdthong, A., Khejornsart, P., Kang, S. 2016. Effect of treating sugarcane bagasse with urea and calcium hydroxide on feed intake, digestibility, and rumen fermentation in beef cattle. Tropical animal health and production, 48, $1123-1128$.

Hall, M.B. 2000. Neutral detergent-soluble carbohydrates. Nutritional relevance and analysis. University of Florida. Gainesville. 76 pp.

Huntington, G. B., and S. L. Archibeque. 2000. Practical aspects of urea and ammonia metabolism in ruminants. Proc. Am. Soc. Anim. Sci. 1999. http://www.asas.org/symposia/proceedings/filename Accessed Oct. 04, 2019.

Kaneko, J.J., Harvey, J.W., Bruss, M.L. 1997. In: Kaneko, J.J.; Harvey, J.W.; Bruss, M.L. Clinical Biochemistry of Domestic Animals. 5th ed. London: Academic Press, p.885-906.

Kaneko, J.J., Harvey, J.W., Bruss, M.L. 2008. Clinical Biochemistry of Domestic Animals. 6th ed. San Diego: Academic Press. 904p.

Licitra, G., Hernandez, T.M., Van Soest, P.J. 1996. Standartization of procedures for nitrogen fractionation of ruminants feeds. Animal Feed Science and Technology, 57, 347-358.

Lopes, J., Evangelista, A.R. 2010. Fermentative and bromatological characteristics and population of yeast of sugarcane silage enriched with urea and with additive absorbent of humidity. Revista Brasileira de Zootecnia, 39, 984-991.

Meira Jr, E.B.S., Rizzo, H., Benesi, F.J., Gregory, L. 2009. Influência dos fatores sexuais e etários sobre a proteína total, fração albumina e atividade sérica de aspartato-aminotransferase e gamaglutamiltransferase de ovinos da raça Santa Inês. Brazilian Journal of Veterinary Research and Animal Science, 46, 448-454.

Mertens, D.R. 1994. Regulation of forage intake. In: Fahey Jr., G.C. (Ed.). Forage quality, evaluation and utilization. Madison: American Society of Agronomy, p.450-493. 
Mertens, D.R. 2002. Gravimetric determination of amylase-treated neutral detergent fiber in feeds with refluxing in beakers or crucibles: collaborative study. Journal of AOAC International, 85, 1217-1240.

Morais, J.B., Susin, I., Pires, A.V., Mendes, C.Q., Oliveira Junior, R.C.O., Packer, I.U. 2006. Ingestive behavior of sheep and nutrients digestibility of diet containing soybean hulls. Pesquisa Agropecuária Brasileira, 41, 1157-1164.

NRC. 2007. Nutrient Requirements of Small Ruminants: Sheep, Goats, Cervids and New World Camelids. National Academies Press.

Odhaib, K. J., Adeyemi, K. D., Ahmed, M. A., Jahromi, M. F., Jusoh, S., Samsudin, A. A., Halimatun, Y. Sazili, A. Q. 2018. Influence of Nigella sativa seeds, Rosmarinus officinalis leaves and their combination on growth performance, immune response and rumen metabolism in Dorper lambs. Tropical animal health and production, 50, 1011-1023.

Olafadehan, O.A., Adebayo, O.F. 2016. Nutritional evaluation of ammoniated ensiled threshed sorghum top as a feed for goats. Tropical Animal Health and Production, 48, 785-791.

Oliveira Júnior, R.C., Pires, A.V., Fernandes, J.J.R., Susin, I., Santos, F.A.P., Araujo, R.C. 2004. Total replacement of soybean meal by urea or starea in high grain diets on nitrogen metabolism, ruminal ammonia-N concentration and blood parameters in beef cattle. Revista Brasileira de Zootecnia, 33, 738-748.

Perazzo, A. F., Neto, S. P.H., Ribeiro, O.L., Santos, E. M., Carvalho, G. G.P., Oliveira, J.S., Rodrigues, T. C. G. C., Pinho, R. M. A. 2016. Correlations of intake, digestibility and performance with the ingestive behavior of lambs fed diets containing ammoniated buffel grass hay. Semina: Ciencias Agrarias, 37, 1551-1564.

Perazzo, A.F., Neto, S.D.P.H., Ribeiro, O.L., Santos, E.M., Carvalho, G.G.P., Oliveira, J.S., Bezerra, H.F.C., Campos, F.S., Freitas Junior, J. E. (2017). Intake and ingestive behavior of lambs fed diets containing ammoniated buffel grass hay. Tropical animal health and production, 49, 717-724.

Polli, V.A., Restle, J., Senna, D.B., Almeida, S.R.S. 1996. Rumination of bovine and bubaline steers in feedlot regimen. Revista Brasileira de Zootecnia, 25, 987-993.

Przemysław, S., Cezary, P., Stanislawc, M., Krzystof, L., Barbara, P., Zofia, A., Maja, F., Katarzynaa, Z., Zabek, K. 2015. The effect of nutritional and fermentational characteristics of grass and legume silages on feed intake, growth performance and blood indices of lambs. Small Ruminant Research, 123, 1-7.

Pugh, D.C., Dum, M.S. 2005. Clínica de ovinos e caprinos. São Paulo: Edições Roca, 1150p.
Ramos, J. P. F., Santos, E. M., Santos, A. P. M., de Souza, W. H., \& Oliveira, J. S. 2016. Ensiling of Forage Crops in Semiarid Regions. In Advances in Silage Production and Utilization. InTech.

Rezaei, J., Rouzbehan, Y., Fazaeli, H., Zahedifar, M. 2013. Carcass characteristics, non-carcass components and blood parameters of fattening lambs fed on diets containing amaranth silage substituted for corn silage. Small Ruminant Research, 114, 225-232.

Santos, F.C.O., Mendonça, C.L., Silva Filho, A.P., Carvalho, C.C.D., Soares, P.C., Afonso, J.A.B. 2011. Biochemical and hormonal indicators of natural cases of pregnancy toxaemia of in sheep. Pesquisa Veterinária Brasileira, 31, 974-980.

Santos, R.D., Neves, A.L.A., Pereira, L.G.R., Sollengerger, L.E., Rodrigues, J.A.S., Tabosa, J.N., Vernerque, R.S., Oliveira, G.F., Jayme, D.G., Gonçalves, L.C. 2016. Agronomic traits, ensilability and nutritive value of five pearl millet cultivars grown in a Brazilian semi-arid region. Journal of Agricultural Science, 154,165-173.

Shakeri, P. 2016. Pistachio by-product as an alternative forage source for male lambs: Effects on performance, blood metabolites, and urine characteristics. Animal Feed Science and Technology, 211, 92-99.

Silva, H.G.D.O., Pires, A.J.V., Cunha Neto, P.A.D., Carvalho, G.G.P.D.U., Veloso, C.M., Silva, F.F.D. 2007. Digestibility of nutrients in diets containing ammoniated elephantgrass and cocoa meal or palm kernel cake fed to sheep. Revista Brasileira de Zootecnia, 36, 499-506.

Van Soest, P.J. 1994. Nutritional ecology of the ruminant. 2nd ed. London: Constock.

Van Soest, P.J., Robertson, J.B., Lewis, B.A. 1991. Methods for extraction fiber, neutral detergent fiber and nonstarch polysaccharides in relation to animal nutrition. Journal of Dairy Science, 74, 35833597.

Ward, J. D., Redfearn, D. D., McCormick, M. E., Cuomo, G. J. 2001. Chemical composition, ensiling characteristics, and apparent digestibility of summer annual forages in a subtropical doublecrop-ping system with annual ryegrass. Journal of Dairy Science, 84, 177-182.

Publisher's note Springer Nature remains neutral with regard to jurisdictional claims in published maps and institutional affiliations. 